\title{
Kissing Frogs \\ Do Psychologists and Bankers Live in Different Worlds?
}

Souleles, Daniel

Document Version

Accepted author manuscript

Published in:

Ethnos

DOI:

10.1080/00141844.2019.1705870

Publication date:

2022

License

Unspecified

Citation for published version (APA):

Souleles, D. (2022). Kissing Frogs: Do Psychologists and Bankers Live in Different Worlds? Ethnos, 87(5), 833850. https://doi.org/10.1080/00141844.2019.1705870

Link to publication in CBS Research Portal

\section{General rights}

Copyright and moral rights for the publications made accessible in the public portal are retained by the authors and/or other copyright owners and it is a condition of accessing publications that users recognise and abide by the legal requirements associated with these rights.

Take down policy

If you believe that this document breaches copyright please contact us (research.lib@cbs.dk) providing details, and we will remove access to the work immediately and investigate your claim. 


\section{Kissing Frogs: Do Psychologists and Bankers Live in Different Worlds?}

\section{Daniel Souleles}

Journal article (Accepted manuscript*)

\section{Please cite this article as:}

Souleles, D. (2019). Kissing Frogs: Do Psychologists and Bankers Live in Different Worlds? Ethnos. https://doi.org/10.1080/00141844.2019.1705870

This is an Accepted Manuscript of an article published by Taylor \& Francis in Ethnos on 26 Dec 2019, available online:

DOI: http://www.tandfonline.com/10.1080/00141844.2019.1705870

* This version of the article has been accepted for publication and undergone full peer review but has not been through the copyediting, typesetting, pagination and proofreading process, which may lead to differences between this version and the publisher's final version AKA Version of Record.

Uploaded to CBS Research Portal: May २०२० 
Kissing frogs: Do psychologists and bankers live in different worlds?

Daniel Souleles

Associate Professor

Copenhagen Business School

Department of Management Politics and Philosophy

Porcelænshaven 18A

2000 Frederiksberg

Denmark

ds.mpp@cbs.dk 


\begin{abstract}
Organizational psychology consultants and valuation bankers are essential to creating employee stock ownership plan companies (ESOPs). However, bankers and organizational psychology consultants see the world in different ways and in fact, paradoxically create different sorts of companies from the same companies, engendering an ontological pluralism. This pluralism suggests that social change can happen on a large scale without persuading everyone there is only one way to see or be in the world. In fact, it's possible that ESOPs are as successful as they are because they are a sort social form that exists differently for various people, while still making line employees wealthier than they otherwise would be.
\end{abstract}

Keywords: Organizational Psychology, Investment Banking, ESOPs (Employees Stock Ownership Plan Companies), Culture, Change, Ontology

\title{
Say brother, have you heard the good news? Have you heard of the ESOP?
}

Forgive the millenarian zeal in the above heading for a moment and ponder the Employee Stock Ownership Plan company, the 'ESOP': An ESOP is an ownership scheme in which employees of a company own shares in a trust; the trust, in turn owns some portion of the company. As the underlying company makes more or less money, the trust becomes more or less valuable, and employees become more or less rich. In this model of a business, a model that has only existed in its present legal form in America since the mid-1970s, employee wealth is directly tied to the financial fate of the company in which they work ${ }^{1}$. Far from fringe, ESOPs make up a significant proportion of the American economy. In 2015, there were around 7,000 ESOP businesses in the United States, employing around 14,000,000 people, with trusts valued at around US\$ 1 trillion (NCEO 2015a, 1). To add some perspective, in that same year the US labour force was roughly $140,000,000$, meaning that somewhere around $10 \%$ of workers in America are in an ESOP (Bureau of Labor Statistics). Not only do a lot of people work in ESOPs, but ESOPs seem to run the gamut of possible company size and industry: the largest

\footnotetext{
${ }^{1}$ Many ESOPs offer supplemental retirement benefits, such as employee-matched $401 \mathrm{k}$ accounts, to mitigate this risk
} 
majority employee-owned ESOP is Publix Super Markets, a grocery store chain based in Lakeland, Florida. It employs 175,000 souls. The sixth largest ESOP is Amsted Industries, a Chicago, Illinois based industrial components manufacturer that employs 16,800. And for some variety, the $18^{\text {th }}$ largest majority employee-owned ESOP is Sterling Global Operations, Inc., a Lenoir City, Tennessee based Security and Munitions Services company, employing 5,500. In our age of rampant income inequality (Stiglitz 2013; Piketty 2014), perhaps it's enough to note that there is a scalable, viable model of sharing the wealth generated in a capitalist firm. Moreover, it's a model that works across industry and geographic location ${ }^{2}$. Yet, there is more to the ESOP story: ESOPs seem to do better than comparable non-ESOP companies. Employees tend to get paid more, get laid off less, and are under less managerial supervision (Kruse et al. 2010). Freeman et al. $(2010,22)$ suggest that when all of this happens in an ESOP, it is happening due to a latent variable, 'corporate culture'. Put slightly differently, it seems that in ESOPs that are more successful than comparable non-ESOPs there is an internal shift in the company in which the affect of employees changes such that employees have pride in their company, and think that they own it, acting in it with a heightened level of care and responsibility. Moreover, managerial employees foster this sort of open environment, relying on collaborative managerial techniques instead of more conventional hierarchical ones (Souleles

\footnotetext{
${ }^{2}$ Part of this has to do with the fact that ESOPs are a specific type of business corporation and corporations themselves are instantiated legally via a genre of documents that are replicable across company types (see Latour 1986 on "immutable mobiles" and specifically his discussion of paperwork and metrology in his final section). Businesses generally can do all sorts of different things and still be, legally speaking, corporations. The same goes for the sub category of ESOP. Put another way because ESOPs have a generic legal form, their mode of property ownership and employment can co-occur with all sorts of different kinds of businesses in the U.S.A.
} 
2019). A question arises, though, how do such companies come into being? How do you make an ESOP with an ownership culture?

It was precisely this question that I spent two years, roughly from Winter of 2015 through Spring of 2017 investigating. To answer this, I conducted 88 life-history and ethnographic interviews with 76 informants. Perhaps $1 / 3$ of these interviews were preliminary and wide ranging, covering people in ESOPs as well as supporting industries like law firms, consulting firms, industry research foundations, etc. The latter $2 / 3$ of the interviews took place in an organizational consulting firm (Values Inc.), a banking firm (Lemur Limited), and an ESOP defense contractor (Sapphire Solutions). I selected these three companies because they all work with each other, and provide a case-study in the creation of an ESOP with an ownership culture. Lemur Limited does the annual stock market valuation for Sapphire Solutions. And Values Inc. has done managerial coaching for Sapphire Solutions to teach people how to lead an ownership culture. This paper will largely concern the difference between Values Inc. and Lemur Limited, despite the fact that both are necessary for creating an ownership culture. I deal with Sapphire's ownership culture elsewhere (Souleles 2019a).

At Values Inc., I spoke to every employee of the consulting firm, save one, talking to nine people in total. At Lemur Limited I spoke with everyone in their ESOP valuation group who would talk to me, 14 people of perhaps $16^{3}$. Beyond the interview work, I spent six weeks doing on-site field-work in Philadelphia, New York, Chicago, Cleveland, Washington D.C., and in a Small Southern Town, dividing my time roughly evenly between these three firms. In addition to

\footnotetext{
${ }^{3}$ The count is imprecise because people, particularly at the junior level move in an out of specific groups at this financial services firm. Moreover, the organization as a whole was growing fairly rapidly. Any precise count was a moving target.
} 
interviews and field work, I attended 5 ESOP conferences and accumulated an archive of ESOP literature.

The cumulative effect of this field work was to persuade me that, should you want to create an ESOP with an ownership culture, you would need to have equal parts a willing company, the intervention of organizational psychologists/consultants (or some equivalent) to teach people how to be owners and managers how to run a company for owners, and valuation bankers to put a price on the company so the ESOP trust could take shape, have a monetary value, and, ultimately buy shares from people when they retire or leave the company, thereby cashing out. Put slightly differently, and gesturing towards the point of this essay-it seems that to create an ESOP with an ownership culture, that is, a capitalist firm that employees get rich from and seem to be treated relatively well in, you need the collaboration of psychologists and bankers, people, who I will argue, have different ways of seeing the world, perhaps different fundamental ontological commitments to the world they live in, and, as a consequence, work to create very different companies.

In what follows, then, I will illustrate these two ways of seeing companies, show how these different ways of seeing lead to the creation of different companies based on different understandings about the nature of companies, and ultimately suggest that this may be an important case in social transformation. If to create an ESOP you need the collaboration of people with different ontological commitments, different ways of seeing the world, and if an ESOP is the sort of social organization we'd like to salvage from the wreckage of exploitative capitalism (following Gibson-Graham 2006 or Tsing 2015), then we need to understand the dynamics of cross-ontological collaboration. We need to understand how people who fundamentally live in different worlds come together in a common social project. 


\section{What do we see when we're around people?}

I have claimed that organizational psychologists and investment bankers see the world in fundamentally different ways, and that the coexistence of these differences in the context of the creation of an ESOP is part of what allows social change to happen. I aim to illustrate that below, but first, I should explain what I mean by 'seeing differently.'

Marilyn Strathern (2013) in a series of lectures called 'Learning to See in Melanesia,' given at Cambridge University, outlines what it means to see differently, and how the world changes with different ways of seeing. She notes that the title had, 'in truth, a textual origin. This was in Anthony Forge's description of how boys and men from Abelam, Papua New Guinea, acquire expectations about what they will see in flat, two-dimensional paintings displayed on the elevated facades of ceremonial houses. One outcome was their inability to interpret other twodimensional images (as in photographs) outside the orbit of such paintings, for everything else would be three-dimensional' $(2013,8)$. In this origin story, Strathern is gesturing to the way in which particular sets of learned expectations shift how one sees, understands, and interacts with the world. A photograph is a two-dimensional sketch, a chemically-preserved impression of photons representing, on a nearly flat plane, some past three-dimensional scene, if you are trained how to see it. Without this training, there is no photograph, just a funny-coloured card.

Strathern, in turn, starts her lecture, juxtaposing three different ways of seeing the social scene at various places in Papua New Guinea - that of an America-based artist and photographer, that of a generic social anthropologist, and that of some of the people Strathern has worked with in Melanesia. Each way of seeing selects different details form the social world, and creates different sorts of social beings, processes and realities from those ways of seeing. 
The first way of seeing, 'an indigenous visual theory...in this case a Euro-American one,' (Strathern 2013,26) is that of an artistic photographer. Strathern shows a series of photographs of Papua New Guineans dressed for community events. However, the artist frames his photographs in such a way that we only see isolated individuals, generally against a neutral backdrop, often with a focus on their face. Strathern describes this as, 'a Euro-American model of the person: costume is like the roles that people put on 'over' their raw nature' $(2013,26-7)$. What this amounts to, is showing, 'Papua New Guinean people's artistry as it might look if we were looking for 'Papua New Guinean artistry' via Euro-American conventions' $(2013,27)$.

Strathern confesses that, 'The overall effect the photographer's pictures has on me [is] isolated bodies removed from social context' $(2013,40)$. She goes on to offer another way of seeing, that of a social anthropologist, one that seeks to place people in context. She illustrates this by showing pictures of similar sorts of people that are in the artist's isolated photos, now, however, at large public, ceremonial, and festive gatherings that involve wealth exchange, at 'Mokas'. She notes what she sees: no one seems to sit; the whole body is meant to be seen (2013, 41); no one sees the individual, rather they see a mass $(2013,42)$; 'one should see the decorations not the dancers' $(2013,43)$. Whereas the photographer saw individuals beneath costumes, Strathern sees social interconnection and a complicated whole - a perspective she attributes to her training as a social anthropologist.

Finally, Strathern offers a third way of seeing — her theorization of what Papua New Guineans see at a Moka. She does so by walking through the elements of the Moka exchange that the artist's subjects were dressed for, and that she offered her own pictures of. She observes that, 'dances take place in the open, in daylight, to be seen so spectators can see' $(2013,49)$. She then shows the lined-up pearl shells that fill up the moka ground (2013, 50-51). Then she shows 
pigs laid out for eating and exchange. And then she comes to the spectators, watching the whole thing asking, '...what do the spectators affirm? What is their role? They are witness to the activity of these men, both production: internal growth, and exchange: flow of wealth between donors and recipients, elicited as clans, big men, and so forth. In brief, you disguise the individual but reveal the person [as a nexus of relations]' (2013, 53; Strathern 1990). Commenting on the accumulated social weight of all this ornamentation, all these prestations, Strathern says, 'We could thus say that the way in which persons draw others' attention onto themselves makes themselves the object of other persons' regard. It is deliberate. They want others to look at them (at certain times, not other times). The person is objectified: in the regard of others [he or she] is turned into an object' $(2013,15)$.

Taken together, these three different ways of seeing create altogether different social worlds, and offer a bridge to the sort of ontological pluralism I suggest obtains in the case of ESOPs. For the euro-American photographer there are individuals pulled out of context, shining from beneath a costume. For the social anthropologist these people are part of a social scene, an elaborate festival of conviviality and exchange. And, according to Strathern, for Papua New Guineans, people are the breadth of social relationships they display and wear. To call them individuals, or to say that there are whole people in a social scene misses the Melanesian point. There simply aren't people in the same way that there are for the anthropologist or for the photographer. This all comes back to seeing: what details of the world are important, and then cobbled together into social reality, a social reality that is then treated as though it were a natural fact. What's more, we can move a step beyond seeing to ontology.

Ontology is a slippery concept. I use it to mean the actual factual stuff that makes up our world. An 'ontological claim' is one that makes some judgment about what is real, about what 
exists. An 'ontology' is a schema identifying and classifying the real world that people live in. Ontology is usefully contrasted to 'epistemology' which means a knowledge or truth generating system. An epistemological system generates truth claims about ontology, that is, what is. These different ways of viewing and constructing reality that Strathern describes create social entities that move and have consequential afterlives beyond the acts of observation (Harman 2016, 42 on 'symbiosis'). People, seen one way or the other become real in that particular social register and live on in a Moka's web of exchange relationships, an anthropologist's lectures and theorizing, or a photographer's circulating work.

It's not so easy to parse the existential implications of all this, either. Each iteration of social reality, each different ontological claim exists as the world that a given person or group of people actually occupy. Acknowledging this conjures the question of what circumstances allows these differences to arise in the first place. Annemarie Mol gestures to this sort of dilemma in her study of arteriosclerosis in a Dutch Hospital. She notes that different medical practices give rise to different arterioscleroses - and that the diagnostic tools employed in say, an individual case study reported by a patient, a microscopic analysis of dead flesh and cells by a lab technician, and the surgeon's first-hand observation of opened arteries arise out of, 'an endless list of heterogeneous elements that can either be highlighted or left in the background depending on the character and purpose of the description' (2002: 26). What matters for Mol, though, are the social processes that assemble these heterogenous elements into particular, real diseases for whomever is doing the diagnosing.

Beyond the creation of ontological plurality, these ways of seeing have definite and different pragmatic effects (James 1921, 44), leading to different treatments and lives for patients in the case of arterial disease, and different capitalization opportunities and life/work worlds for a 
social enterprise liken an ESOPs. This naturally segues into a larger discussion of what to make of plural ontologies, particularly if we want to build something shared, like an ESOP, that will have to wait for the conclusion. For now, though, it's enough to appreciate how social seeing, in Strathern's sense of things, creates different social worlds, and how the practices of these different social worlds create different lived realities, in the case of Mol's doctors, patients, and technicians.

\section{Of Two Minds}

As I noted above, to make an ESOP with an ownership culture you need, at a minimum a willing company, some manner of 'ownership' or 'culture' training, and investment bankers/lawyers/transaction people to create legal and financial entity that makes up the financial reality of ownership. I suggested that the curious thing about this is that you have the coordination of two groups of people, organizational consultants/psychologists and valuation bankers/investment bankers/transactions advisers, who see the same ESOP and potential ESOP companies in consequentially different ways. Some related literature will help get a sense of the larger sweep of these distinctions and prepare the way for a close ethnographic accounting of these differences.

We might start, as Strathern did, with the details that each group finds important in a company. The employees of Virtue Inc., embrace thick description (Geertz 1973), that is nuanced, close accounting for social context. They also pay attention to the multiple, dynamic inner-lives interacting within a given company. They use this attention to psychological lives as the mechanism by which they seek to change a company, in this case to create an ownership culture. Too, this is what we might expect of organizational psychologists. 
The 2017 issue of the Annual Review of Organizational Psychology and Organizational Behavior gives a sense of this worldview. Across 20 articles, we hear about self-determination and autonomous motivation and how institutions can foster such phenomena (Deci and Olafsen 2017); the structure of emotions in the workplace and the benefits of happy employees (Askanasy and Dorris 2017); the social function of team and group work (Knippenberg 2017); the nature of ostracism and incivility in a workplace (Ferris, Chen, and Lim 2017); and how verbal and non-verbal communication function and differ in an organization (Keyton 2017), and so on. What emerges across this heuristic, and what I will suggest is also manifest in how Virtue, Inc., apprehends a company is an appreciation for human psychological life in all its complexity as being the constitutive causal matter that makes up an organization.

By contrast, the financial professionals at Lemur Limited may be described as maestros of thin description (Holmes and Marcus 2006; see also Holmes 2013), that is translating complex social life to abstract, in this case numerical representations. Much like the financial analysts Holmes and Marcus describe, the people at Lemur Limited seek numerical traces of a firm's activities - the balance sheet, the income statement, the cashflow—all those standard instruments of financial accounting — and create a company in the form of a numerical price. Researchers have noted this form of numerical sensemaking as widespread among financiers and allied business professionals: Karen Ho (2009) has described financial analysis of various businesses as the core analytic activity among investment bankers; I (2019) have described similar professional practices among private equity investors; Caitlin Zaloom (2006) and Hirokazu Miyazaki (2013) have described different financial traders who understand general economic activity via the quantifiable movement of tradeable, abstract, investment instruments that are meant to stand as a proxy of underlying assets; And Kimberley Chong (2018) has shown the way in which 
management consultants transform organizations with an eye toward how investors will interpret them via their stock valuation. We might say that this adds up to a sort of calculative ethos (Appadurai 2012; Miller 2008), a sense that the story of a given company is told via its accounting documents, and that what you might need to know about sickness, health, planning for the future, creditworthiness, etc., can emerge from this sort of calculation based on thin, context-less data ${ }^{4}$ that ultimately produces the greatest abstraction of all: a numerical price ${ }^{5}$.

As I noted above, culture work and accounting work are necessary for a healthy ESOP. The question, then, is what does thick description, and what does thin description look like when we're talking about a business? And, perhaps, prior to any of that, who are these people, and how does thin or thick description come to be sensible to them?

\section{Will anybody miss me if I'm gone?}

To my mind, figuring out thin and thick description, seeing differently, in the context of an ESOP starts with people's backgrounds and how they understand the work they do in the context of their larger life story. Everyone I talked to at Virtue Inc. had a story about both dissatisfaction with past work and the sense of moral purpose training people for ownership offered. Often, I'd hear a sequence of companies that just didn't get it - treated employees poorly or had a far too limited social mission. Huliang Ha, a junior consultant fit this model to a T. She noted that how

\footnotetext{
${ }^{4}$ Keep in mind, just because some data are thin or contextless, doesn't mean that people don't care about them, or don't make extremely consequential decisions based on them. As we'll see below, data can motivate all manner of destiny for a firm.

${ }^{5}$ It's worth noting, too, that there appears to be a gendered component to all of this: at Virtue I spoke with two men and seven women; and at Lemur I spoke to three women and 11 men. Elsewhere (Souleles 2019b: 33ff) I've noted the preponderance of men in banking and suggested that this often seems to line up with a bias towards abstracted modes of analysis that are amenable to universal application. This, in turn, is in contrast to Virtue's mode of deeply contextual thinking. Perhaps this is yet another instance of nuanced care-work being pushed to a women-controlled space.
} 
she got to Virtue Inc., 'was ideologically informed but not a direct route.' She graduated from an elite American private university, and started working as a financial services consultant. There, she said, she was a, 'typing analytical monkey,' and didn't want to do the job long term. She noted that she wasn't a big crier, but come Sunday night she would be in tears at the prospect of returning to work.

So, she quit after four months on the job, and went to work for a non-profit lending firm, in their consulting arm, doing training and education for nonprofits. While the work was more morally acceptable than mortgage banking, she still felt dissatisfied. She felt, 'like the whole non-profit sector was a band-aid-yes, these people do exploitative things then they give money to philanthropy, then philanthropy tries to bandage the problems.' She had a, 'sense [that] there are bigger structural problems with the economy that the non-profit sector isn't solving.' To her and her colleagues minds the creation and spreading of ESOPs and ownerships culture is a scalable shift in the fabric of capitalism. The work is meaningful because it sees a worthy social goal, worker's empowerment, and growing worker's wealth, and seeks to move companies in that direction.

Lemur Limited, being a financial services firm, is a study in contrasts. Bruce Bobble, a junior analyst when I met him, now an associate, told a different bildungsroman to Huilang:

Daniel: How do you see what you do for a living as similar or different [from what other people in your family do]?

Bruce: It's very different. I mean, I don't really know how to even start answering that question, to be honest. I guess, like, well my brother was always a much different thinker, my brother was like a Classics major in college and all that kind of arts and sciences, liberal arts types stuff, whereas I'm not really one for that kind of stuff. I'm more of a numbers type...my sister was kind of artsy too actually. Buy, yeah, I don't really know how; one of my cousins works in finance as well. He is at [a major investment bank]...so I think that's like how I ended up, I talked with him a bunch before I started studying finance. I think that might be how I ended up here... 
D: What was it in the conversation that this seemed like a good idea?

B: So, I don't remember the exact quote, but it was something about how if you understand economics you understand how everything works.

More than anything specific, Bruce has a sense that the economic, the numbers as opposed to the artsy/science-y is the key to explaining the world. It's different from the liberal arts. If you want to have a sense of how the world works, learn econ.

Bruce, as junior as he may be, was not alone in this sentiment. I found something similar among his colleagues and superiors - a pragmatic, practical approach to business and life. Many people had finance or economics majors, most wanted a stable, reliable, and remunerative career. Insofar as there was any great emotional or value-laden attachment to the work it was due to the fact that numbers made sense in a kind of deep explanatory way. Beyond that, meaning, if people wanted it, would have to come from some further abstraction from the work-it was good to help create ESOPs, or Lemur Limited's people and culture were good; it was a good place to be.

Not everyone needed a further abstraction, nor was Lemur's work based on one.

Jared Jones, one of Bruce's Managing Directors, gets at this sense of things:

Jared: As for us, and people like us, we're just a piece of the puzzle. More like a chess piece, but we're not the chess masters...We could just as easily be doing other types of valuation assignments; and that's how I started my career. I didn't evolve into ESOP work because I found some inner, you know, workings inside me that wanted to do that.

$*$

J: $\quad$...So, I'm not a dreamer. When I went to [college], one of the reasons I went right into the school of management, I knew in my mind what I was good at, and more importantly what I wasn't good at. Foreign language were very tough for me. The physical sciences, actually everything except math sometimes was a struggle for me. So I went right to the school of management, was majoring in accounting probably from my sophomore year...

Without putting too fine a point on it, the way Jared describes himself is not the way that Louise or Huilang describe themselves. Jared chose what to his mind was a sensible path through 
college, accounting, that would guarantee a comfortable life. He also sees his work on ESOPs as more or less interchangeable with other financial tasks. As Bruce told us, there is an economic element to everything.

Bruce, Jared, and Huilang are standing in as particularly clear exemplars of what I generally found at Lemur Limited and Values, Inc. Values Inc had people who struggled in their lives and careers to live out their deeply held values. They do what they do because they feel that teaching about ownership cultures and advancing ESOPs is basically good. There should be more ESOPs with ownership cultures in the world. By contrast, folks at Lemur sound much more value neutral. They think ESOPs are great, and some perhaps feel it's better to work on ESOPs than other types of financial products, but insofar as great meaning comes from their work it comes from this higher level of abstraction, or the charitable work they do above and beyond their day job, and the community and culture they make at Lemur. Jared points out that he explains that he could just as well be doing anything else in finance.

In these capsule biographies and exegeses, we're starting to gather different ways of seeing. Bruce and Jared see things quantitatively, economically. To me at least, it doesn't seem terribly surprising that they make their living reducing complexity and producing thinly described prices of companies. By contrast, Huilang and her colleagues seek notice complexity of social scenes, and are deeply wounded when they are in a place that doesn't reflect their sense of how the world should morally work. Again, it doesn't surprise me that in their daily lives, they're concerned with the lives, in all their messy complexity of the people and companies they work with. In fact, they couldn't do their work without this deep human connection. These contrasts are further helpful in that they provide a bridge to a closer explanation of what Lemur and Virtue, Inc. do to and for the companies they work with 


\section{Kissing Frogs}

When a company comes to Values, Inc., they typically want, in Value, Inc.'s schema, one of three things: 1) cultural communication, 2) leadership training and coaching, and/or 3) help with strategic planning. What this practically means is that companies seek help explaining what exactly an ESOP is, and generating the right expectations to foster an ownership culture among workers and management (cultural communication); companies seek help training and coaching their leadership and management such that they can manage in a more egalitarian consensusdriven fashion (leadership training and coaching); and companies seek help planning for large changes in their organization, such as leadership transitions, expansions to new markets or news sites, the addition or attrition of employees, all to ensure that the special ownership culture of the company persists (strategic planning. Specific consulting engagements can involve any of the above three types of activity, in any combination, for just about any length of time. Values Inc., will often come in for a few-hour presentation on what an ESOP is. Values Inc. also has been coaching some people for years.

So, what do people hire Values Inc. to do, at least in their own estimation? Greta Grapeseed, a past president of the firm says that, 'I think our overarching thing is that people should have and be able to participate in and affect decisions that affect their lives. It has to be done in a realistic way; everyone can't participate in everything. It's not talking about voting on the colour of the wall in the bathroom. In between those, there [is] a lot of space-what [is] the place where people can be involved? Who has the expertise? [Then,] trying to get [leaders to have] a participative mindset — who should be in the room? Who has knowledge? Whose input do we need to engage in the process?' All told, Greta tries to make a workplace more participatory, along the lines of what being an 'owner' would suggest. This is in equal parts communicating 
with people what realistic expectations are: you can have a role in consequential decisions that affect you - while you may not have a say in the colour of the bathroom. While you may not supervise the accountant if you're a design engineer, you will have a role in defining your own job expectations and the circumstances of your work. In turn, this almost immediately spills into leadership training.

Often leadership training and coaching starts with some sort of 360-degree assessment (people above and below a person in a work hierarchy evaluate them) as well as individual personality inventories such as the Meyers's Briggs, the EQI for emotional intelligence, and a number of other similar assessments. One consultant described the goals of some of these assessments as trying to, 'show on a day to day basis what someone's strengths are,' or as trying to, 'get at [how the person] acts under stress or extreme exhaustion, what are the tendencies? Are you someone who flips out under pressure and yells at everybody?' They also try to determine 'what makes you tick?' what sorts of values you have, things like, 'tradition, and affiliation, and altruism... are you more motivated by wanting to have power [or] helping other people.' All this, ideally builds towards a sort of self-awareness that allows an individual manager to be both aware of their strengths, limitations, and tendencies, and, in turn, open to coaching which is designed to amplify strengths and ameliorate limitations with the goal of creating a leader that can facilitate a collaborative flatter ownership culture.

At another point in her interview, Louise Linden identified the way in which coaching connects to the larger realm of strategy work they do with companies. She noted that it, 'fit in the context of larger systemic work [and that it was] more powerful at a systems level.' What she means is that, when you have a properly coached CEO or manager they are able to implement strategies, plans for their firm, that allow more participatory management structures. Instead of 
managing executives going offsite, coming up with a strategic plan, and then having the plan imposed on employees, a leader, with the help of someone like Louise, would generate revenue and performance targets from their employees and then collaboratively turn that into a strategic plan.

Given that so much of what Values, Inc. does is predicated on psychodynamics-identifying and changing the way in which people frame, understand, and then act on their work lives, the boundary conditions of Values' work is readily apparent. And, the boundary has to do with motivation and aptitude. Often when discussing companies, they would identify a few repetitive motivations that would occur among owners and managers. Among these were: 1) a sense of obligation to one's employees who helped build your company; 2) a sense of moral imperative coming from an often-Christian religious background; 3) a sense of secular political purpose in ameliorating inequality; 4) a desire to leave a monument or a legacy in the company you own or run; and 5) a desire to make money (though this one was often subsidiary or at least co-occurring with the other values). In so categorizing, Values, Inc. identified a sort-of value rationality (Weber 1978, 24-26; e.g. O’Mahony 2006) — that is people hold ideas about that which is valuable and worthwhile, and often subordinate strict maximization to those values. This seems to be a prerequisite to their work — value rationality. And when it is absent or weak, we might expect their work to fail. This turns out to be the case.

Greta put it this way, 'it doesn't work if people don't have the appetite for it, [don't have] the underlying belief that employees know something.' She went on to note that lots of places don't care to train their middle managers, who, often due to their interstitial position in the larger hierarchy, don't have much motivation to act in any way other than according to predictable and narrow expectations of a company's leaders. She is alluding to the fact that many people don't 
value the input or ideas of their subordinates. There can be individual limitations to Values' approach as well: one consultant pointed out that often people are conflict averse and insecure and consequently can't take coaching. They feel too exposed. And, perhaps most generally, many firms have a fixed idea that one leader should run the show and fail to see the point in expanding the managerial process and creating owners. In one way or another all these lacks and limitations point to when Values, Inc.'s work doesn't work, when there is an absence of values that they can work with in the course of their training and interventions. In Greta's words, in the search for companies with values, they end up 'kissing a lot of frogs.'

For an ESOP to function it needs to have a price at two different occasions: its sale, and its annual valuation. To form an ESOP trust, the company needs to be bought from its previous owner by the ESOP trust. And for this to happen the trust and the company need a fair market price. Without a fair market price, the federal government in the form of the Department of Labor would intervene and prevent the sale or sue parties trying to manipulate the process. Then, once an ESOP exists it needs a price every year so that it can value the shares employees own. In turn, the company has an obligation to purchase a retiring or departing employees shares at that 'fair' price. Generally, however, prices of companies are determined in competitive auctions or via stock market. Given that no such social mechanism exists for an ESOP price determination ( Beunza, Hardie, and MacKenzie 2006; Muniesa 2007), this is where Lemur Limited is of use. They create a price. They create a price for an ESOP transaction; and they create a price annually for the ESOP's stock valuation.

One analyst described the basis of what they do in creating a price, 'we're essentially taking the balance sheet and understanding the inputs of assets and liabilities, essentially what 
they're worth, how they impact the results of the company, then we're taking input from management, creating assumptions, creating a discount rate...try to normalise historical and projected earnings...compare them to public companies that are similar in nature, learn some information about them...' In other words, this is taking a company's financial information, information about similar companies, historical comparative price information, data about comparable transactions, and coming up with several plausible prices for a company. The root of one such price would be the 'discounted cash flow method' in which the future revenue of a company is predicted, and then 'discounted', or reduced into a price that one would pay today (Svetlova 2012). The idea is that as potential money recedes further into the future, it is worth less than money you might have now (Souleles 2019b, 153), so when you figure the price of a company now, you should discount it accordingly. The art of valuation is wrapped up in what you select as an appropriate discount rate.

Admittedly, this is a simplification of a complicated, months long accounting research project. The people working at Lemur Limited not only have to factor in esoteric accounting concerns like different forms of debt and odd issuances of stock for unusual companies, they have to do it in a way that they feel would withstand the scrutiny of an often-adversarial US Department of Labor, or, ultimately a judge. For our purposes, though, it's enough to appreciate that much of what they do is designed to 1) predict future cash flows of a company, and 2) appropriately discount it to arrive at a fair current price. To do so, they have to take in the entire financial situation of the company and its industry, as well as esoteric things like how much they trust management and how confident they feel in their company, and make a judgment call.

As I noted above, the employees at Lemur, are financiers who happen to work on ESOPs. They love and appreciate and cheer for more ESOPs, extolling the extension of ownership. But, 
at the same time, many of them can imagine working in other industries in finance in a way that many employees at Values, Inc. cannot imagine moving on. This is reflected in a theory of human motivation that I heard from time to time at Lemur, here voiced by one of Lemur's ESOP groups founding partners, 'I do think that when people have skin in the game...they are more efficient, they work smarter, they work harder...most employees who don't have skin in the game it's a job; if you have skin in the game, it's a career.' This is basically a transactional theory of motivation (or instrumental rationality, if we want to continue following Weber [1978, 24])_-if you own something, if you have property, you care about it, and you will rationally work to maintain or better your individual position. Otherwise, if you don't own it, why would you care? This is different from the above value rationality that Values, Inc. sought in their companies. Moreover, this assumption about motivation is reflected in the actual practice of Lemur Limited. I repeatedly heard that there is actually no way to account for an 'ownership culture' in the valuation of a company. One associate noted, 'There is no line item that says improved morale or culture, nope, no...it is not explicitly recorded in any part of the [financial] analysis.'

Firms like Lemur Limited and Values, Inc. are necessary to creating an ESOP with an ownership culture. Basically, someone needs to come up with a price, and someone needs to teach how to be an owner. Yet, across all areas of their professional service practice they see companies differently. Values, Inc. sees value-rational actors, pays attention to psychological life and well-being, and sees a company as a complicated social place. Lemur Limited reduces a company to an accounting abstraction, and sees rational actors motivated by ownership and protection of property. Yet for all these differences, both ways of seeing are necessary to make an ESOP. 


\section{Do they see different companies? What difference would it make, anyway?}

ESOPs are curious - the prevailing myth of winner take all capitalism in America would seem to preclude a scheme that spreads ownership stakes to employees. Yet, there they sit, occupying around 10 percent of the American economy. Even more strangely, they flourish due to the interaction of two very different groups of people - the folks at Lemur Limited, the ESOP valuation division of a financial services firm, and the folks at Values, Inc., an organizational consulting firm. Moreover, those different groups of people don't really have to interact much with one and other, or their opposite's representations.

Strathern above suggested that groups of people can see the same phenomenon differently, and in fact seem to enter into a different reality as a consequence of what they see and understand. Mol develops this sort of insight, suggesting that different practices create different versions of the same objects. I suggested that this was a decent point of entry for thinking about the difference between Lemur Limited and Values, Inc. To this end I described the different ways people at each firm see their lives and interact with, thereby creating companies. Rather than recapitulate all of this in greater detail, I'll show a few examples of how they describe and understand companies differently:

Here is an analyst from Lemur Limited after I asked him about an interesting company: Jebb James: ...this is actually really cool cause you know the tax benefits of ESOPs right?

Daniel: I know some of them, but feel free to walk me through.

J: $\quad$ OK, so usually if it's a C corporation there's like two tax levels, you're going to get taxed on the company side then you know if you have dividends or personal taxes you're going to get taxed on that too. This was an S Corporation ESOP, $100 \%$ owned by the ESOP so they're not paying any taxes whatsoever...

They took those tax savings back in like 2004, they basically ran a run-off company that, this company makes like machinery for like food and beverages, nothing really exciting. 
But, they started this life sciences company, they produce a lot of the machinery for the biotech industry. It's been growing extremely fast, it's got a lot of potential, and they recently sold that. They sold a majority interest in that run off company.

D: $\quad$ To the ESOP?

J: No, to a private equity firm.

D: $\quad$ So they are an ESOP and they have a division the spun off into a private equity firm?

$\mathrm{J}: \quad$ Yeah, that was really interesting cause you never really see that.

The story here is all about earnings and taxes and growth opportunities and sales. The company becomes a revenue generator that reinvests capital, spins off divisions, and sells. We don't hear about culture. We don't even hear about people

Frank Fern, the current president of Values, Inc. is a study in contrasts, again, after I asked about interesting companies they work with:

Frank: I have [an electronics manufacturer] that I adore working with in [New England] that, really is uses me in unfortunately very small ways, mostly around employee owner education, about their ownership and to some extent the business. The company is really a deeply values driven company and is a real leader in the things we like and care about. They make interesting products, they have an interesting mission orientation, they treat their employees particularly well, they have a high degree of work force engagement in a variety of ways that I think are inspiring...

Frank talks about the values that this company has, the way they treat their employees, and, in fact, the product they make. Frank tells a human story highlighting that which he admires. In parallel, Jebb tells an accounting story, also filled with that which he admires.

Given the difference in how they both see these companies I think there is a theoretical point to be made and a pragmatic point to be made, both in the service of illustrating how people with different ways of seeing can come together to affect social change. First the theoretical: For some time, there has been a debate about the ontological status anthropologists ought to grant to different ways people seem to exist in the world (for an overview and a recapitulation of 
these discussions see Holbraad and Pederson 2017, particularly their lit-review on p. 8). Simply put, how seriously do we take people who seem to live in a different world than the one we experience? Do we reduce their claims by deracinating theorizing? Or do we grant them independent, self-determining ontological primacy, accepting that perhaps we have multiple worlds and that we should go have a discussion with our colleagues in the physics department? (see Gell 1992, 54ff on exactly this question). Holbraad has suggested the following:

The alternative, as a number of anthropologists and philosophers have been arguing for some time, must be to reckon with the possibility that alterity is a function of the existence of different worlds per se. On this view, when the Nuer say that twins are birds, the problem is not that they see twins differently from those of us who think twins are human siblings, but rather that they are talking about different twins. The interesting difference, in other words, is not representational (read 'cultural') but ontological: what counts as a twin when the Nuer talk about it as being a bird is different from what counts as when one talks about it as being human, having a certain kind of DNA and so on. [Holbraad in Venkatesan Ed. 2010, 183]

In a proof of this sort of thinking, Tanya Luhrmann has in fact demonstrated that local differences in theories of mind change the ways in which people know God: 'the more social importance placed on mental experience — at least as a secular means of self-understanding - the less people will judge that God speaks in a way they can hear with their ears' $(2017,139)$. She goes on explaining, 'In the mind-minded US setting, where minds are imagined as private and bounded, shut off from the world, but where thought is thought to be socially so very central, the people interviewed in this study were least likely to say that God spoke to them in an audible voice they heard outside their mind, and most likely to experience God speaking inside their minds' (139). Taken together, she seems to be taking the ontological differences in the manifestations of God seriously. Moreover, she is tying it to different local theories of mind. The theory of mind shifts, God changes. 
Something similar is going on with organizational consultants and valuation bankers. They have incommensurably different premises about what makes up a business. Consequently, in the course of their work they both create and interact with fundamentally different companies, even if they are interacting with the same business. For one group of people it's a pack of feral numbers waiting to be abstracted, counted, reduced, tamed, and interpreted. For another group of people, a company is a congeries of psyches and values waiting to be coached, encouraged, and consoled. Though it's paradoxical, they seem to create different companies out of the same companies. They seem to have, at least in a limited way, a different ontology, a different world they live and interact in. If something as central and all-encompassing as God can be ontologically different for Pentecostal Christians in different parts of the world, I don't think it's too much to say that companies can be fundamentally different depending on your interpretive starting points, depending on how you see people and businesses ${ }^{6}$.

This in turn leads to a pragmatic question - What does it matter, what practical effect does it have that I can show that organizational consultants and valuation bankers see companies differently and in fact seem to have different ontological realities when it comes to the businesses they both work with? Most basically it suggests that to affect social change or even collaborate on some shared task, people don't need to share fundamental ontological commitments. Differently seeing people can work on a common task, like the creation of an ESOP. Too, this shifts our question not so much to how do they see differently, to questioning

\footnotetext{
${ }^{6}$ Just as there has been a substantial conversation within anthropology about extending ontological self-determination to the folks that we study, or at least taking their ontological premises seriously, there's been an equally coherent and persuasive argument against radical ontological difference as it may serve to re-inscribe the tired anthropological trope of an irretrievably "savage" other (see for example Bessire 2014).
} 
what allows for this plurality in the first place, as many of us could likely conjure no shortage of instances of ontological difference (the Protestant reformation, anyone?) leading to social strife?

A few people, two very nice gray-haired lawyers whom I met at an ESOP conference, who were both around at the creation of the ESOP carve-out in the US tax code in the 1970s shed some light: They explained that ESOPs demanded no particular form of governance-a trustee was a steward of the employees' shares, but as to how the company actually had to run itself, there really wasn't any specification. Companies could be conventional capitalist firms with executives and boards of directors if they so choose. Companies could also democratise, have pass through voting on all major issues including budgets and hiring the CEO, should they like. Really, it could go any which way, and still be an ESOP, still allow employees to own shares in a company and grow wealthy or poor with the place they worked. They felt that this sort of ambiguity in the law has allowed ESOPs to prosper in a number of different states, with a number of different companies, all with a variety of management strategies and differing levels of hierarchy. The law set up a tax structure and some minimal amount of accounting standards for an ESOP. As to what they looked like, that was more or less up to the individual companies. The law allowing for ESOPs allowed for the type of ontological plurality that has grown up around them ${ }^{7}$.

Insofar as there is any lesson we might learn from the rise of ESOPs and the ontological plurality they seem to carry, it's this: to affect social change you don't need to have everyone on the same page or persuade everyone that they're even in the same reality. Rather, you may be able to create a space for maximal difference within some kind of minimal constraint. ESOPs

\footnotetext{
${ }^{7}$ For more on the history of ESOPs see Blasi et al. 2014. For more on the long history of collectivism in the United States see Curl 2009. For more on the concept of the corporation and corporate ownership see Mackin 2015.
} 
have to have trustees, and can't allow former owners to swindle workers. But, after that, they can run any which way they want, allowing plenty of space for people to learn to be owners.

Acknowledgments: Thanks you, Christian Borch, Kristian Bondo Hansen, Michael Scroggins, Morten Axel Pedersen, and Marilyn Strathern for tolerating early versions of this article and offering helpful critique.

Funding: This research was funded by a Louis O. Kelso fellowship from the Rutgers School of Labor and Management Relations.

Disclosure Statement: The author currently holds no financial interest or benefit in the direct application of this work.

\section{References}

Appadurai, Arjun. 2012. The Spirit of Calculation. Cambridge Anthropology, 30(1):3-17.

Ashkanasy, Neal M. and Alana D. Dorris. 2017. Emotions in the Workplace. Annual Review of Organizational Psychology and Organizational Behavior, 4:67-91.

Beunza, Daniel, Lain Hardie, and Donald MacKenzie. 2006. A Price is a Social Thing: Towards a material Sociology of Arbitrage. Organizational Studies, 27(5):721-745.

Blasi, Joseph, Richard Freeman, and Douglas Kruse. 2014. The Citizen's Share: Reducing Inequality in the $21^{\text {st }}$ Century. New Haven: Yale University Press.

Bureau of Labor Statistics (n.d.) Labor Force Statistics from the Current Population Survey. http://data.bls.gov/pdq/SurveyOutputServlet?request_action=wh\&graph_name=LN_cpsbref1 . Accessed November 7, 2015.

Chong, Kimberley. 2018. Best Practice: Management Consulting and the Ethics of Financialization in China. Durham: Duke University Press.

Deci, Edward L., Anja H. Olafsen, and Richard M. Ryan. 2017. Self-Determination Theory in Work Organizations. Annual Review of Organizational Psychology and Organizational Behavior, 4:19-45.

Ferris, D. Lance, Meng Chen, and Sandy Lim. 2017. Comparing and Contrasting Workplace Ostracism and Incivility. Annual Review of Organizational Psychology and Organizational Behavior, 4:315-339. 
Freeman, Richard B., Joseph R. Blasi, and Douglas L. Kruse (2010) Introduction. In Shared Capitalism at Work: Employee Ownership, Profit and Gain Sharing, and Broad-Based Stock Options. Douglas L. Kruse, Richard B. Freeman and Joseph R. Blasi eds. Pp. 1-37 Chicago: University of Chicago Press.

Geertz, Clifford. 1973. The Interpretation of Cultures. New York: Basic Books.

Gell, Alfred. 1992. The Anthropology of Time. Oxford: Berg.

Gibson-Graham. J.K (2006) A Postcapitalist Politics. Minneapolis: University of Minnesota Press.

Harman, Graham. 2016. Immaterialism. Cambridge: Polity Press.

Ho, Karen. 2009. Liquidated: An Ethnography of Wall Street. Durham: Duke University Press.

Holmes, Douglas and George E. Marcus. 2006. Fast Capitalism: Para-Ethnography and the Rise of the Symbolic Analyst. Frontiers of Capitalism. Melissa S. Fisher and Greg Downey, Eds. Durham: Duke University Press.

Holbraad, Martin and Morten Axel Pederson. 2017. The Ontological Turn: An Anthropological Exposition. Cambridge: University of Cambridge Press.

Holmes, Douglas. 2013. Economy of Words. Chicago: University of Chicago Press.

James, William. 1921. Pragmatism: A New Name for some old ways of Thinking. New York: Longmans, Green and Co.

Keyton, Joanne. 2017. Communication in Organizations. Annual Review of Organizational Psychology and Organizational Behavior, 4:501-527.

Knippenberg, Daan van. 2017. Team Innovation. Annual Review of Organizational Psychology and Organizational Behavior, 4:211-235.

Kruse, Douglas L. Richard B. Freeman, and Joseph R. Blasi Eds (2010) Shared Capitalism at Work: Emplyoee Ownership, Profit and gain Sharing, and Broad-Based Stock Options. Chicago: National Bureau of Economic Research.

Latour, Bruno. 1986. Visualisation and Cognition: Drawing Things Together. In Knowledge and Society: Studies in the Sociology of Culture Past and Present. H. Kuklick (ed.). Pp. 1-40. Jai Press (6).

Luhrmann, T.M. 2017. Knowing God. The Cambridge Journal of Anthropology, 35(2):125-142. 
Mackin, Christopher. 2014. Defining Employee Ownership: Four Meanings and Two Models. Paper prepared for the Annual Meeting of the American Economic Association, Boston, January 2015.

Miller, Peter. 2008. Calculating Economic Life. Journal of Cultural Economy, 1(1):51-64.

Miyazaki, Hirokazu. 2013. Arbitraging Japan: Dreams of Capitalism at the End of Finance. Berkeley: University of California Press.

Mol, Annemarie. 2002. The Body Multiple: Ontology in Medical Practice. Durham NC: Duke University Press.

Muniesa, Fabian. 2007. Market technologies and the pragmatics of prices. Economy and Society, 36(3):377-395.

National Center for Employee Ownership (NCEO) (2015a) Employee Ownership Report. 35(2).

National Center for Employee Ownership (NCEO) (2015b) America's Largest Majority Employee-Owned Companies. Employee Ownership Report, 35(4) July-August: 8-9.

O’Mahony, Siobhán. 2006. Developing Community Software in a Commodity World. In Frontiers of Capitalism. Melissa S. Fisher and Greg Downey. Pp. 237-267. Durham: Duke University Press.

Piketty, Thomas (2014) Capital in the Twenty-First Century. Arthur Goldhammer trans. Cambridge: Harvard University Press.

Souleles, Daniel. 2019a. Another workplace is possible: Learning to own and changing subjectivities in American employee owned companies. Critique of Anthropology (0)0:1-21.

Souleles, Daniel. 2019b. Songs of Profit, Songs of Loss: Private Equity, Wealth, and Inequality. Lincoln: University of Nebraska Press.

Stiglitz, Joseph (2013) The Price of Inequality: How Today's Divided Society Endangers Our Future. New York: Norton.

Strathern, Marilyn. 2013. Learning to See in Melanesia: Lectures given in the Department of Social Anthropology, Cambridge University, 1993-2008. haujournal.org: Hau Master Class Series. https://haubooks.org/learning-to-see-in-melanesia/. Accessed December 21, 2017.

Svetlova, Ekaterina. 2012. On the performative power of financial models. Economy and Society, 41(3):418-434.

Tsing, Anna Lownhaupt (2015) The Mushroom at the End of the World. Princeton: Princeton University Press. 
Venkatesan, Soumhya Ed. 2010. Ontology Is Just Another Word for Culture. Critique of Anthropology, 30(2):152-200.

Weber, Max. 1978. Economy and Society. Berkeley: University of California Press.

Zaloom, Caitlin. 2006. Out of the Pits: Traders and Technology From Chicago to London. Chicago: University of Chicago Press. 